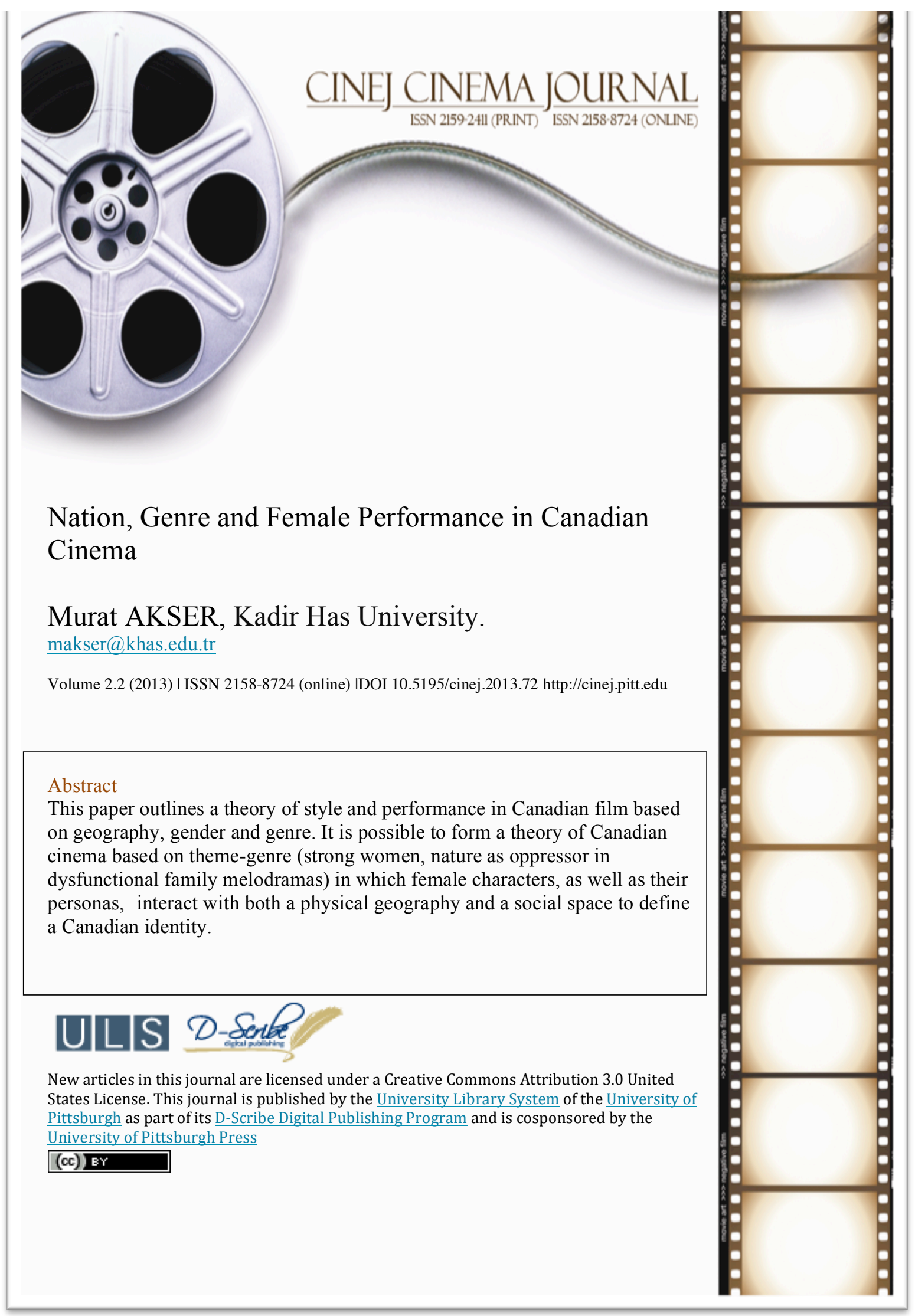




\section{Nation, Genre and Female Performance in Canadian Cinema}

\section{Introduction}

This article aims at broad questions but has to be humble in its conclusions. Can there be a theory of a Canadian national cinema? This is the overall question underlying this study. In my discussion of contemporary Canadian Cinema since 1996, I outline a theory based on geography, gender and genre. In my opinion, it is possible to form a theory of Canadian cinema based on theme-genre (strong women, nature as oppressor in dysfunctional family melodramas) in which female characters, as well as their personas, interact with both a physical geography and a social space to define a Canadian identity. This expression of a Canadian identity includes the relationship between humans and nature, men and women, French and Anglo, born Canadians and newcomer immigrants and others complicated by class, place, race and ethnicity-based identities. But recent films, whether produced by newcomers with the assistance of federal funding or by reputable and established names, women characters stand out as powerful figures in opposition to a passive male. Thus, this paper makes the assertion that strong female personas translate to a Canadian identity that is defined against its neighbor, the United States and against its cinema, Hollywood cinema. The strong male figure who saves the world is a metaphor for the American government/culture/cinema based on the construction of macho male heroes or alternatively another common depiction is passive female characters awaiting a prince. It is that metaphor of the timid female waiting to be saved that Canadian cinema refuses to duplicate. Through a reversal of roles, Canadian cinema presents powerful female personas with intellect, attitude and sensitivity. This reversal of roles renders the macho male character of Hollywood cinema impotent (and empowers the Canadian male as sensitive and intelligent). This metaphorically significant achievement of Canadian cinema is also ironically nuanced by how these films are financed and distributed. Canadian films are made with tax dollars and have comparatively smaller distributions. Yet artists may find it easier to express radical artistic views in a more autonomous way without having to be concerned about box office returns. The downside, of course, is that such films do not enjoy broad circulation. Nonetheless, the desire of these independent filmmakers has made possible the creation of an artistic cinema with daring potential. And it is the female character in this cinema that creates a metaphor, and there is a sense of cultural and social space in their personas. The attitudes and attributes of these women, the social and physical space they occupy and the way they drive the narrative as well as the form (colors, lighting) will be the main focus of this study. I will analyze three films in detail: New Waterford Girl, The Sweet Herafter and Kissed. These

CINEJ Cinema Journal Nation, Genre and Female Performance in Canadian Cinema

Volume 2.2 (2013) I ISSN 2158-8724 (online) I DOI 10.5195/cinej.2013.72 I http://cinej.pitt.edu 150 
personas are extensions of Canadian popular female performers such as Liane Balaban, Sarah Polley, Molly Parker, and Genevieve Bujold. When necessary, I refer to their personal histories as well. Because of space limitations I do not discuss other Canadian films that display the themes I mentioned above, but other recent examples could be Suspicious River, Hanging Garden, St. Jude, Stardom, Lost and Delirious, Dead Ringers, Last Night, Ginger Snaps, and Maelstrom.

In order to develop a consistent theory I needed a large sample of films, and those selected are recent films shot and released between 1996-2001. They were shot mainly in four provinces: Nova Scotia, Quebec, Ontario, and British Columbia. I also limit my sample to English speaking films with Anglophone middle class families since a selection larger than this would require a much longer study. The criteria for selection are also based on finance, talent, source of inspiration and content. There is a financial aspect because for a film to be considered Canadian, to the source of funding should be Canadian, whether it be tax dollars or private capital. For that reason I chose films that were developed, filmed and distributed in participation with federal institutions (Telefilm Canada, NFB), local film boards (OMDC) and Canadian producers independent or affiliated with production companies (Alliance Atlantis) in the four provinces mentioned above. Talent is also a critical factor because a Canadian film should have a Canadian cast and crew, either native-born or immigrant. The source of inspiration is important as well because Canadian films often tell stories adapted from Canadian novels or written by Canadian screenwriters. Lastly, content should be taken into account because Canadian films make explicit references to Canadian geography, people, customs and other symbols.

\section{Theoretical Background: Cultural Geography and Identity}

I use an interdisciplinary approach to analyze film texts in social, economic and geographic contexts. Geographical space, as understood via political economist Harold Innis' theories on staples and later on communication, is useful for explicating the interactions of people across a large geography. Canada, which is founded on an east-west continuum (which is undergoing changes since the 1988 NAFTA agreement), is organized around certain staples which has led to a state of colonial dependency, first with the British Empire now with the US. Also, the creation of communication technologies and other infrastructural media like railways are conducive in unification and the creation of identity. ${ }^{1}$

\footnotetext{
${ }^{1}$ Such an east to west union and rupture is observed in the films I analyze. Geographic spaces extend from Newfoundland and Nova Scotia to the Quebec-Ontario Prairies and Atlantic provinces. The centers of production are Halifax, Montreal, Toronto and Vancouver. This leaves out the two significant but independent and marginal centers of Calgary and Winnipeg. Recent films like Gary Burns' Waydowntown and Sean Garrity's Inertia deserve further attention in this regard.
} 
Films represent a form of visual culture and as and as such are representative of identity as well. When dealing with landscape and its influence on culture, it will be useful to drawn on the discourses that have been generated in the field of cultural geography, which point out that people create landscapes and in return they are shaped by them as well (Norton 2000: 1-3). The social and spatial constitution of a society finds its geographic expression of culture in the landscape. Cultural geography sees culture as having three aspects: values and abstract ideals to which members of a group hold, the norms and rules they follow, and the material goods they create. Thus, in this formulation culture is the agent, nature is the medium and the cultural landscape is the result (Norton 2000: 11-13). The new approach offered by cultural geography takes this landscape model even further, focusing on cultures as maps of meaning and looking for the codes with which meaning is constructed, conveyed and understood (Jackson 1989: 2). Physical space is defined by houses, tools, office space, cars, and machines, and it both completes and is in contrast with social space, which is the realm of human interaction family, friends, and people. This includes customs, ways of life and personal points of view. The characters-personas in films are subjectivities and they interact with the geography around them, and in this process their worldviews and identities are shaped. For the new cultural geography, human identity is comprised of eight basic components: place, language, ethnicity, nationality, community, class and gender. In this analysis, I will examine this relationship between place, community and gender and how culture is visualized in Canadian narrative film. The relationship between characters and the spaces they inhabit defines their place in society as regards both physical and social space, home family, school and environment.

Behavior is shaped by social environment, and the perceived subjective environment defines behavior. This model can be used to examine the interaction of women in Canadian films. For example, alienation is a result of a clash between collective identity and individual identity. The concept of place and home is also significant here, and it should be born in mind that home can be a place of oppression and confinement (Norton 2000: 275). In New Waterford Girl Moony's identity represents an identity of resistance against localism and community in favor of a more cosmopolitan one. In The Sweet Hereafter and Kissed the interior is a place of confinement where people find peace. Gender is also clearly reflected in the Canadian landscape.

In her seminal work Weird Sex and Snowshoes, Katherine Monk discusses every major theme in Canadian cinema. In this study I intend to build upon some of Monk's themes such as the social use of landscape, nature's oppression of people and the symbolic interaction between this landscape and people (especially actively creative women). Monk builds a framework for thinking about Canadian cinema which takes into account themes such as the tradition of realism coming

CINEJ Cinema Journal Nation, Genre and Female Performance in Canadian Cinema

Volume 2.2 (2013) I ISSN 2158-8724 (online) | DOI 10.5195/cinej.2013.72 I http://cinej.pitt.edu 152 
from NFB roots, free artistic expression as a result of government funding, a nuanced difference with US cinema in terms of the viewing of nature as an oppressor (rather than men taming nature), strong women-weak men, survivor guilt, obsession with death (rather than the joys of life) and the bilingual and multicultural outsider (rather than assimilation).

Monk talks about the relationship between Canadians and the harsh reality of Canadian winter and tries to explain the reflection of survivor guilt in Canadian films. From the position of the victim, the survivor (of oppressive nature) tackles the landscape which surrounds her as a negative space. This is like the negative space around a sculpture which in turn defines the art object itself, and nature as the oppressor becomes the negative space that stresses humans trying to survive and the home environment. These characters emerge from the wilderness with a better understanding of self (Monk 2001 26-29). Monk also points out that the national art gallery of Canada is full of portraits depicting the contrast between interiors and exteriors, between warm tones and bundled bodies, wood, smoke and old Catholic icons and the great white barrenness outside (Monk 2001: 65). We can see this dangerous white cold landscape and human survival in the paintings of Cornelius Krieghoff and members of the Group of Seven. With this comes the symbiotic relationship between female characters and the landscape (Monk 2001: 71). In this way, landscape can be clearly the other. What I call social environment Monk refers to as positive space such as cars, geography and the physical environment which counter balance oppressive nature (Monk 2001:102).

\section{FILMS, SPACES, PERSONAS}

In a recent collection of articles on Canadian cinema, Andre Loiselle wrote on Don Mckellar's persona in a way that connects landscape and the female persona. Loiselle dissects this male persona and lays out the themes around it (Beard \& White 2002: 239-250). It was found that Canadian male characters are often depicted as beautiful losers while women had strong personas. Similarly, Katherine Monk finds female characters in Canadian films to be strong-willed, highly competent, intellectually superior, decidedly youthful, generally benevolent, physically attractive and outward looking, but also fecund physically and intellectually (Monk 2000: 129-131). In saying this, Monk does not see this empowerment of females in Canadian film as working against Canadian masculinity; Canadian men are not less manly or eunuchs. Their ability to face their weaknesses makes them better and more realistic heroes.

On this point, I argue that this strength of the female persona can be connected to geographic and social space. These spaces influence characters and both the form 
and content of Canadian films. In the physical/geographic beauty of Nova Scotia, with its hills and sea and green nature, can be built a Catholic hell as in Hanging Garden or New Waterford Girl. In the cold white blue of British Columbia there can be hatred, loss of faith and psychotic deviance in a beautiful wasteland as in The Sweet Hereafter and Kissed. The innocence of idealistic characters can be lost in the urban materialistic social setting of Ontario as in Highway 61 and Ginger Snaps. The old European Francophone Catholic setting of Montreal can produce sensual young women who experience difficulty in establishing their identity both in and out of Quebec as in Stardom, Lost and Delirious and Dead Ringers. ${ }^{2}$

\section{Teenage Angst: New Waterford Girl and St. Jude}

New Waterford Girl is the first film I will discuss in terms of the relationship between landscape, social space and female persona. The film's hero is Moony Pottie, a fifteen-year-old Cape Breton girl in the 1970s who wants to leave her hometown to become an artist in New York.

Mooney's environment is defined by blue sky, which is rainy gray most of the time, green grass and wild sea pounding the rocky shore. Nature acts as an oppressive force. Mooney walks along the cliff when she feels troubled. She is sarcastic and hopeless. The moody skies, rocks, wind, and the sea create a sense of isolation and captivity. In this way nature imprisons Mooney.

Mooney's home is the social setting where she is oppressed by a passive father, an overprotective mother, two sexually active sisters, one naïve brother and a kid brother. This is an extended family where the newly married son, Fletcher, brings the bride to live with the family. Mooney has no room; she lives (in between) in the hallway. At home the colors get warmer. The interior is red and orange. Interestingly the film starts with both a wedding and a funeral. The bride's father is dead and the couple has both a wedding and a funeral at the same time. In the wedding the women wear orange dresses, the boys wear brown and the men wear blue and yellow. This is where Mooney differs from them by wearing a white sweater. As Mooney becomes freer in spirit and her actions, she starts wearing strong warm colors such as red.

\footnotetext{
${ }^{2}$ There is good evidence that certain actors choose projects that have certain personas in them. For example, Molly Parker plays sexually deviant female personas in Kissed, Suspicious River and Center of the World and plays Sarah Poley as an angry young woman trying to break free from a protective family background. Liane Balaban appears twice as an angry teenager trapped in small towns whereas Jessica Pere is cast three times as a sensual and shy Montrealer in Stardom, Lost and Delirous and similarly Polly Shannon in the recent CBC mini-series Trudeau. We find Genevieve Bujold as the prototype of the sensual Montrealer in the recent Dead Ringers and Last Night.
} 
It is always essential to identify strong willed Canadian women when contrasting them with men. After the introduction of this banal setting, we see the arrival of Mooney's sidekick (or alter ego) who comes from New York, the city of her dreams, as a savior. Lou is a young girl whose father is in prison and she comes to New Waterford (because it is the end of the railway) with her mother and younger brother. Lou is the direct opposite of Mooney. She is outgoing, sexually aware and experienced. She can take care of the house and can manage her mother and brother. In addition, because of her boxing champion father she also can take down older and bigger men with a single punch. We can see the contrasting elements in Mooney's and Lou's personas as below:

$\begin{array}{ll}\text { Moonie } & \text { Lou } \\ \text { passive } & \text { active } \\ \text { inexperienced } & \text { experienced } \\ \text { dependent } & \text { independent } \\ \text { Catholic } & \text { agnostic }\end{array}$

In this social space there are either townsfolk (us) or outsiders (them). Outsiders can be men like Mooney's teacher Cecile Sweeney who lives in a gray trailer literally on the edge of a cliff or the New Yorker family of Lou. Lou learns the meaning of being an outsider when she is chased by the town girls. She scares them by referring to their Catholic beliefs. Mooney also does not fit in, even though she is from within. Because her actions are different in the social setting she was born into, her behavior is interpreted as being abnormal. She resists going to parties, and prefers to read, and she writes bizarre drama pieces as homework and refuses to be a nurse as her parents dictate (in a twisted ironic statement her mother says: "You cannot even be normal in a town this size!"). Thus Mooney is forced to go to a doctor (who cannot cure his own hand scar) and take tranquilizers which leave her numbed to existence.

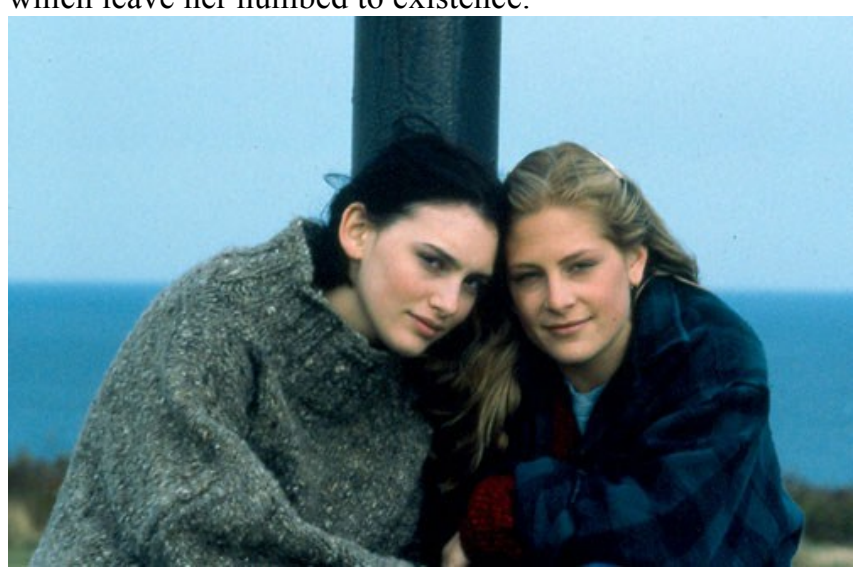

Figure 1. Angry teens of New Waterford Girl 
In this cultural setting of a Nova Scotia community, the favorite pastime is watching hockey on TV. The outside world is referred to as something evil. Mooney's parents complain about her sister's bad mood after her trip to Toronto from which she never recovered. Another social phenomenon is young girls getting pregnant and to avoid shame and gossip they are sent to Antigonish. There they give birth to their children and then leave them with their aunts and come back. The most important institutions in New Waterford are the church, school and the hospital. We see Mooney experience alienation in all of these. Mooney is destined to be a nurse but the hospital has an incompetent doctor who cannot take care of his bleeding hand. She has to confess her sins every Sunday and ask for penance at the church. The school utilizes rote learning through textbooks but without breathing life into the education. This social space (negative within a negative space) isolates Mooney even more. She breaks down all these barriers and as a result she is excommunicated. First she decides to be an artist, and leaves the town for New York. Then she becomes sexually aware, kissing every boy she meets. Ironically Mooney's wait for a divine sign to resolve her destiny comes in the form of a mute boy who walks on the shore. Her status is interpreted as a change from metal to slut. Mooney overwhelms the town boys, rendering them powerless by taking the initiative herself: kissing them first and undressing in front of them. Her long time love interest, Joey, is speechless, and is unable to control himself when she takes him to an alley and undresses. The most he can do is to yell "I had her too!" when she starts kissing every boy she sees on the street. This weakness is emphasized with Lou's strength and her ability to beat men. The arrival of this American neighbor contrasts with the Catholic lifestyle of Mooney. Lou brings her music, sex life and stereotypes of Canada, asking if they all fish here. Her experience of the car ride to main road of the town is embarrassing because unlike American roads this small fishing town has only a one lane road. Lou's agnostic attitude also challenges the role of religion in this small town. After hitting one of the men who got a girl pregnant, Lou is believed to be sent by the Virgin Mary to avenge pregnant girls. This approach works for a while and Lou beats all the men who impregnated girls and left them. Boys seek to redress their reputations by asking Lou to fight a professional boxer. Even that boxer is beaten by Lou, rendering men even more powerless.

Nonetheless, Katherine Monk points out that not all men are weak and this soft emotional attitude is far stronger in terms of the dramatic strength of the characters. For example Mr. Sweeney is as a seen passive and weak man. Yet he is the reason for Mooney's artistic development, and he helps her get a scholarship. Sweeney makes the ultimate sacrifice, believing that he is the father of the child. Thus he attracts the wrath of Mooney's mother and his trailer at the cliff disappears. Sweeney had come to this town to find himself, which he does through this experience with Mooney. Mr. Sweeny gives up his outsider status and the

CINEJ Cinema Journal Nation, Genre and Female Performance in Canadian Cinema

Volume 2.2 (2013) I ISSN 2158-8724 (online) I DOI 10.5195/cinej.2013.72 I http://cinej.pitt.edu 156 
sacrifice he makes out of his love for Mooney makes him the most positive male character. Mooney's father is also a nice character. He bakes cakes when he gets upset. He claims he also had hopes but had to give up and "woke up one day with five kids." He also cannot say speak up to his wife and shuts up when Mooney raises her voice

$\begin{array}{ll}\text { Moonie } & \text { Sweeney } \\ \text { outsider (from within) } & \text { outsider (from without) } \\ \text { young } & \text { old } \\ \text { Mary } & \text { Christ/holy ghost } \\ \text { leaves } & \text { stays }\end{array}$

Thus New Waterford Girl contains the themes discussed above, namely that of a strong young woman trying to find herself. She is isolated because of her attitude towards cultural institutions, and this leads her to seek out a legitimate identity. In this way she takes on an identity of resistance and acquires allies (Lou and Sweeney). Nature and these institutions work as negative space around this female persona. Eventually she survives and leaves the town. Yet there are those who can never leave and have to live with their sins. Continuing with the theme of sin and guilt, the next section examines another strong woman in the survivor film The Sweet Hereafter.

\section{Survivor's Guilt: The Sweet Hereafter}

The Sweet Hereafter, as Monk points out, is the ultimate story of survivor guilt. It is about parents who live on after the death of their children, as a morality tale populated by major characters who try to restore symbolic order in society. Once again contrasting weak men with strong women, the film illustrates the qualities of a dominant female persona. This too is a film about landscapes and people's relationship with them, and colors also play a major role. The film takes place in a small town in British Columbia on the outskirts of the Rockies. The natural outside environment is completely dead, covered by white snow. The social environment is suburban and a mechanical wasteland lies in between: a circus full of metal junk and aburnt school bus are the major objects made by humans that occur throughout the film.

The two main characters are Mitchell Stevens, a lawyer who is troubled by his daughter's illness, and Nicole (Sarah Poley ${ }^{3}$ ), a wanna-be rock singer who was paralyzed after a crash but now sings fairy tales to children.

\footnotetext{
${ }^{3}$ Sarah Polley must be the single actor of her generation to appear in more than 30 feature films and acclaimed television series, and firmly established herself as a film director at the 
In this story of ultimate family disintegration, dysfunction and guilt, nature appears again as an oppressive force. The dominant colors in the film are steel-blue and white. The snow and Rocky Mountains are soft, cold, deadly and white. In this cold blue isolation of the individual, the yellow school bus represents a defective and catastrophic man-made instrument. It is the same with Nicole's wheel chair as if it is the extension of the bus wreck (like the tale she tells). The color blue appears from the beginning to the end of the film. For example, in scenes with Nicole, blue light falls on the wooden walls in the interiors. When not blue, the sky is pale in opposition to earthly wasteland of mud. Nicole always wears light blue clothes. This is the robe of her innocence and guilt. The bus as wreckage echoes the children's cries to bystanders. Another strong color in the film is red. Zoe wears red, calling from phone booths from out of nowhere. Nicole wears a red shawl that belonged to Billy's wife. Also the entrance to her house is painted in red. After the accident, Nicole wears a white sweater (like a shroud) in the court.

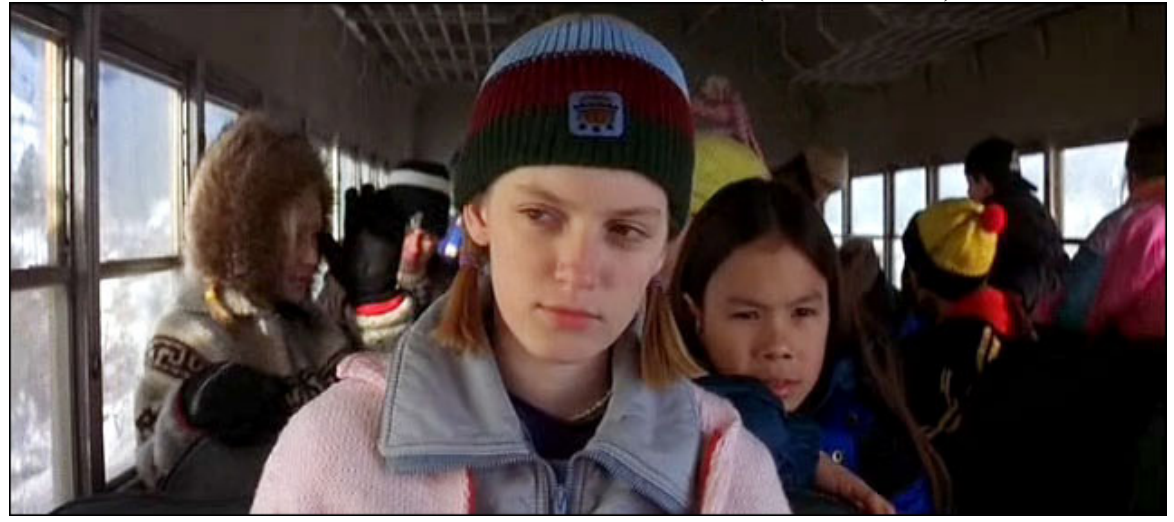

Figure 2. Survivor's guilt in The Sweet Hereafter

age of 23. Polley's background is relevant in her choice of roles and the personas she creates. She is the youngest of five children accustomed to large families with brothers and sisters. Both of her parents were actors and she had her first audition at age five which explains how she started so early. She debuted in films at age 6. Dropping out of high school, she became a political activist for socialist groups, and she lives with her writer boyfriend in Toronto. When she was 12, during the Gulf War, she attended a children's awards show in Washington DC and was seated at a table with some representatives from Disney. They asked her to remove a peace symbol that she was wearing but she refused. Disney has blacklisted her ever since. In 1995 she was attacked by police at a political protest in Queens Park thus firmly expressing her political activism. In 1994 she had surgery to correct scoliosis a sickness related to the dislocation of backbone which may lead to paralyses, an experience she uses well as a paralyzed young singer in The Sweet Hereafter. Her mother died when she was eleven, leaving her an orphan at a young age. 
The strong female personas are Zoe, Nicole and Dolores. Zoe is Mitchell's daughter. She leads an independent life which led to her sickness (AIDS). Yet she can live with the disease and express herself to her father. In return, Mitchell cannot do the same and channels his wrath to the court case he wasn't to build from the bus accident. Nicole on the other hand survives the crash as a cripple. She is the only one who does not mind being in bed or wheelchair all the time. Calm and serene, she lies in the end about the bus accident, putting the blame on Dolores and saving Billy who failed to service the bus. With Nicole, Dolores the bus driver accepts all responsibility for the crash. Dolores's war veteran husband is also paralyzed and cannot talk. When he forces himself to talk he says "Dolores will not sell her soul to you (Mitchell)." After all these events, Dolores finds a job elsewhere as a tour guide. Men in turn are emotionally shut out like Mitchell or angry like Billy under a burden of guilt. In a baptismal war wash scene, Mitchell tries to talk to his daughter through a cell phone. A blue light shines on Mitchell as if to reveal his deadly, cold, rational lawyer world. Her daughter asks, "Why can't you talk to me dad?".

$\begin{array}{ll}\text { mitchell } & \text { zoe } \\ \text { father } & \text { daughter } \\ \text { old } & \text { young } \\ \text { rational } & \text { emotional } \\ \text { mental bloc } & \text { sick body } \\ \text { inarticulate } & \text { expressive } \\ \text { dark } & \text { light }\end{array}$

A similar dilemma exists between Nicole and her father who have a love affair and are not ashamed of it. Nicole is a sinner and thus she is paralyzed after the accident. Now, to redeem herself, she lies and saves Billy from an investigation. This catharsis is generated through a lie. In the end, Nicole occupies the arm chair by herself and asks the motionless father: "Aren't we going dad?" Nicole contains all the opposing qualities:

\section{Child-woman}

love-incest

artist-tale teller

victim-survivor

innocent-sinner

The social space of this town is a very moral space. The kids, truth are important values that are gone and have to be restored. Many sins in the community such as Billy's neglect that leads to the accident, Nicole's incest with her father (which cripples her) and Mitchell's inability to express his emotions to his daughter (she 
gets AIDS). Mitchell's attempts to restore order fail. Nicole restores this order not by sacrificing another soul (Billy's) but offers her own instead. She makes one last radical attempt and lies in order to protect someone and sacrifices her morals. The tale Nicole tells the kids before the accident which keeps on appearing throughout the film is "The Pied Piper of Hamelin." In this tale the piper steals all the kids from a town but only a lame one is left behind (like Nicole who has to live both with a survivor's guilt and the sins of incest and lying.

With a beautiful editing with time and space, the cold and distanced style fits the narrative very well in The Sweet Hereafter, a film in which a strong female persona defies the will of a man and restores the morel order. Finally I will talk about the sexually deviant side of the female persona in Kissed.

\section{Sexual Deviance and Independence: Kissed}

Kissed is a product of the collaboration between two women, Molly Parker and Lynee Stopkewich. Both Parker and Stopkewich are natives of British Columbia. It should come as no surprise that the director imbues the film with beautiful colors and shapes her persona as strong and nature-oriented. The film begins as a flashback. After her lover's death, Sandra Larson experiences a flashback and narrates her story. Sandra is a necrophiliac. She is fascinated by the energy released by death, love turning into hate, and life turning into death in streaks of light cold blue.

In her childhood memories we see Sandra playing with dead animals. At first she buries a dead bird, rubs it all over her body and dances in circles as in a pagan burial rite. In her death-burial rituals as a child, Sandra undresses and dances under a whitewashing light. It is a moment of relaxation and revelation.

Sandra's social settings are limited to her childhood home, funeral home and school. Increasingly, nature plays a role in her life, stealing living beings away as she tries to capture their energy. Sandra's childhood home is pink and orange. The same strong blue light shines from outside through her room window. Day and night are reflected as dead and alive. We have only a few glimpses of Sandra's family. We learn that her father works as a flower shop owner. Her mother only appears in the menstruation scene. The only person we know from her childhood is Carol, her best friend who runs away after she sees the blood of the nail rat they bury and dance around. 


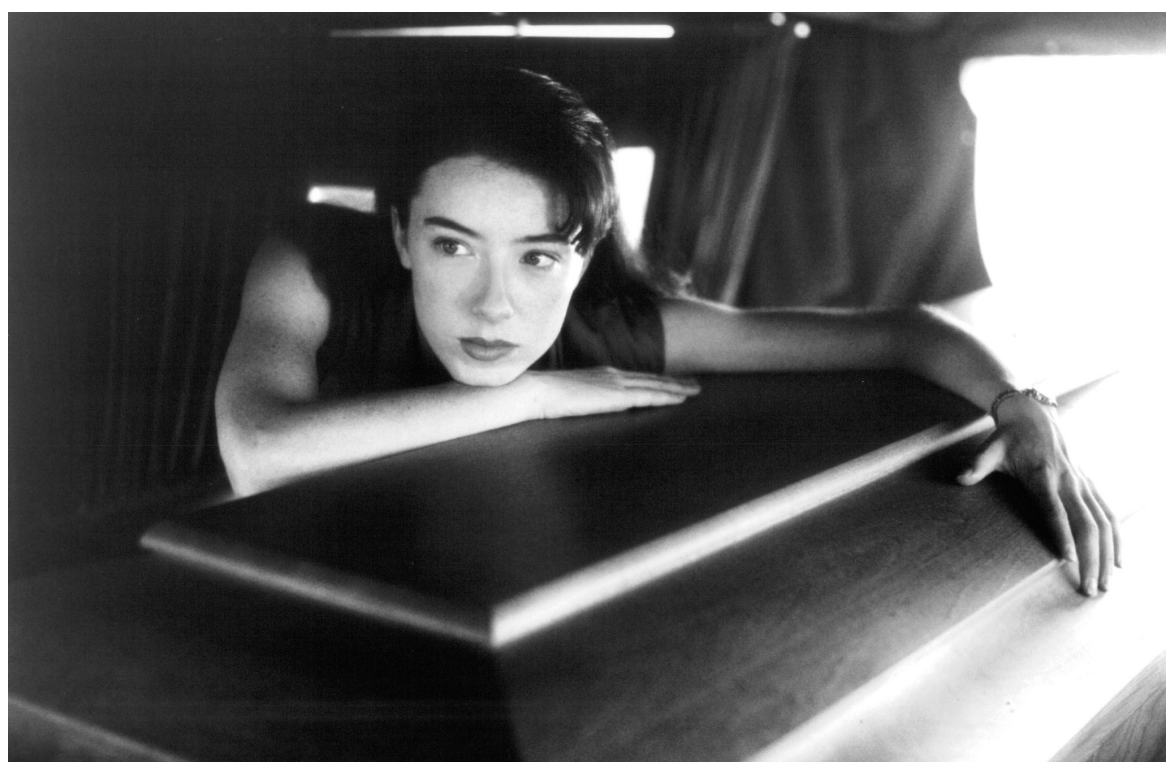

Figure 3. Encounter of the living and the dead in Kissed

The green colors of nature are contrasted with cold dead urban interiors. The strong green outdoors contrasts with indoors, a cold blue washing out to white (death). Red is the color of death and is the blood of dead people and of menstruation. Sandra is caught between many dilemmas throughout the film: She is caught between life and death, between love for a man or sex of a corpse, nature vs. man-made industry, body vs. flesh and sexual satisfaction vs. sexual deviance. Interestingly enough, she survives all these confrontations. Sandra Larson is surrounded by colors. Green outdoors is a brightly colored but it is dead. White is alive as is the sexual organ and dark red, the color of dead blood, of the rat she finds and her menstruation blood, the indication of the end of the fertility cycle, of life giving.

Another important of color related to Sandra's persona is steel blue turning into white. This is the color Sandra experiences in transcending the world of the living to the world of the dead, the ultimate expression of her sexual and spiritual satisfaction. Brown is the medium of the living, it is the color of indoors and social relationships. It is the color of funeral home Matt's house and cafeteria where they meet. Pink is a feminine color, and Sandra wears pink hair pins at home. 


$\begin{array}{lll}\text { Color } & \text { Location } & \text { Emotion } \\ \text { green } & \text { outdoors } & \text { isolation/dead } \\ \text { brown } & \text { indoors } & \text { social sphere/human/living } \\ \text { steel blue } & \text { mind } & \text { start of journey } \\ \text { white } & \text { mind } & \text { transcendence } \\ \text { red } & \text { body/sweater } & \text { realm of the dead } \\ \text { pink } & \text { childhood } & \text { innocence/purity } \\ \text { orange } & \text { home } & \text { belonging }\end{array}$

The color blue and red are dominant in Sandra's adult life, and her eyes are blue just as Matt's. Red is the color of blood as well as menstruation. Sandra wears a red sweater most of the time. In the high school corridors where she experiences the transition from childhood to womanhood the boxes are painted in a spectrum of colors. She wears red at the funeral house.

Again in this film, the female persona is stronger than males'. The male characters all have their weakness like Matt, Sandra's lover, Mr, Wallis, her boss, and a worker. The male personas are weak and passive. The funeral home owner Mr. Wallis is sinister, he has sex with young boy's bodies and ruthlessly embalms their bodies whereas the Catholic spiritual janitor Ian has a similar connection like Sandra. Ian is emotional and judgmental about Mr. Wallis's actions but he cannot do anything about it. He praises older women as Madonnas and looks down on young women who are just skin and bones (remember the skeleton-like image of skinny Sandra). Finally, Matt is such a loser that he commits suicide to communicate with his love. He reports that Mr. Wallis sees the corpses as just dead flesh. Matt is a medical student obsessed with science, order and rationality whereas Sandra is interested in the emotional, transcendental and the dead ${ }^{4}$. Matt attempts to derive ultimate sexual pleasure from Sandra's body but he fails. He is physically satisfied but he wants to have the commitment of Sandra's soul. Sandra's refusal to do this leads Matt to self-destruction. He commits suicide to transcend life so that Sandra can have sex with him. Matt also records Sandra's daily moves, asks about the age and appearance of the corpses Sandra has sex with and even pretends to be a corpse so that Sandra can have sex with him. The worldviews of both characters are diametrically opposite. Matt praises the lifegiving qualities of sperm and blood, sustaining it just like men and women in a relationship of procreation. In contrast, Sandra is after death and what lies beneath. Sandra is a private person. She does not allow light to come through her window, and she uses her own lamp at the cafeteria. She is honest and easily confesses that she has sex with corpses. She is open about her sexuality and tells Matt that she is a virgin on their first night together. The coming together of this unnatural couple is also prevented by nature. When they try to kiss their teeth collide as if to refuse

\footnotetext{
${ }^{4}$ Differences in presenting Canadian women by an American artist can be seen in Mulholland Drive. (see Akser 2012).
} 
the sexual encounter (sex with the living is awkward and unnatural for Sandra). On the first night, Matt wants her to just lie still and do nothing during their first intercourse, to lie down like a corpse). Not satisfied with the experiences of sex with a live man, Sandra goes back to her real lovers at the funeral home. She cheats on Matt with the dead the first night and dances again as she did in her childhood. Matt is also aware of Sandra's strong character, and he calls her complex, complicated and dynamic:

$\begin{array}{ll}\text { Matt } & \text { Sandra } \\ \text { male } & \text { female } \\ \text { sperm } & \text { blood } \\ \text { weak } & \text { strong } \\ \text { ordinary } & \text { enigmatic } \\ \text { life } & \text { death } \\ \text { flesh } & \text { body } \\ \text { science } & \text { religion-occult } \\ \text { rational } & \text { emotional } \\ \text { dissatisfied } & \text { satisfied }\end{array}$

Sandra's strength comes from her quest to transcend life. She tries to penetrate life through the flesh. Her early attempts fail as the mouse is destroyed, the lab mouse which she tries to look inside by cutting into it. In a baptismal scene reminiscent of The Sweet Hereafter, Sandra has sex with a corpse in a car wash. Water symbolically purifies her actions as white light comes from the cascade. Sandra is interested in crossing the boundaries, transforming the energy of life by bringing it back from death. Hers is the ultimate quest, the most difficult task and the most sacrilegious and socially unacceptable behavior. She is daring, unrepentant, and comfortable with her condition; she does not see it as a sickness or weakness. Sandra is interested in embalming and studies at medical school. She see it as a form of torture: vessels injected, mouth stuffed and sealed shut, gems on the eyes, and the blood is replaced with an orange fluid with a phallic-like thick steel long tube stuck right into the central part of the body.

Kissed is a story of sexual deviance, love for the dead, and it is a philosophical and graphic film about love, sex and death. Its female persona appears as a young girl and a young woman. In addition, male characters are also sexually deviant and dissatisfied. Sandra's boss makes love to young boys' corpses (both pedo- and necrophilia). It is a film about contrasting worldviews of science and the occult. The male character has sex without feeling anything for her. Then when he realizes she gets pleasure from dead bodies, he commits suicide to get that pleasure. (He being a medical student interested in the body, and she is interested in the flesh). At the end of the film, the colors change again. In the outdoors, life 
goes from sunshine to rain to dead leaves, just like the cycle of life. Chaos comes again with Matt's death, and Sandra can never belong to the world of the living.

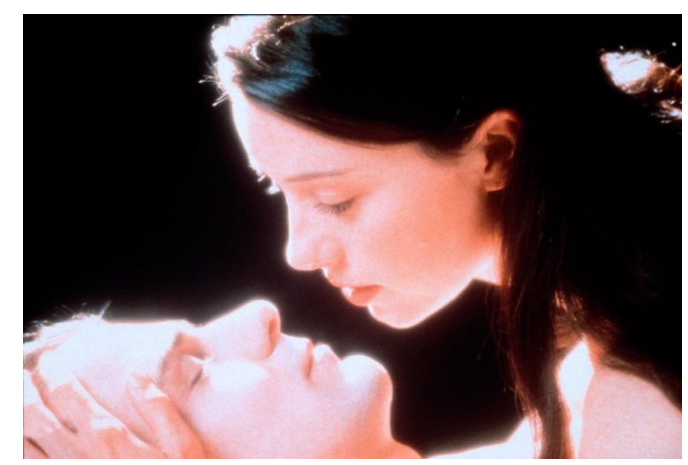

4. A moment of adoration in Kissed

\section{Conclusion:}

In this paper I tried to trace some of the main themes of Canadian cinema in three important films. In all three films landscape played the role of an oppressor as a negative space giving positive room to characters. Warm colors like green and red were contrasted in the films, in the sense that nature with its primary color, green, was offset with women wearing red. Steel blue and white were also oppressive, with orange and grown lively interiors colors. There is also a relationship between geographical space and social space. School, church, and hospital can be oppressive institutions as well as the institution of home as in New Waterford Girl. Moral order is important in small communities and it must be restored at all costs, as in The Sweet Hereafter. Strong female personas, however, are the main driving narrative forces in these films. They are intelligent, sensual, and emotional, and in the end they are forced to bear the guilt of the survivor. Further studies could to look into the relationship between these personas and the actors who perform them. ${ }^{5}$

\footnotetext{
${ }^{5}$ In this paper I only refer to English language films, but there is also the Montreal woman type who is sensual and expressive of her emotions. Such women can be found in Dead Ringers through Genevieve Bujold's character, who is a strong woman that experiences sexual dissatisfaction, although via her sexual deviance and hysteria she can outmatch the two brothers in strength of character. In Last Night she plays a sensual and mature French teacher who crosses barriers and has sex with her younger former student. I would refer to this as a form of French seduction that is reborn with Montreal actors like Jessica Pere in Denys Arcand's Stardom and Lea Pool's Lost and Delirious.
} 


\section{Bibliography}

Akser, M. (2012). Memory, Identity and Desire: A Psychoanalytic Reading of David Lynch's Mulholland Drive. CINEJ Cinema Journal, 2(1), 58-76.

Beard, William and Jerry B. White eds. North of Everything: English Canadian Cinema Since 1980, University of Alberta Press, 2002.

Berland, Jody and Shelly Hornstein eds. Capital Culture: A Reader on Modernist Legacies, State Institutions, and the Value(s) of Art, Kingston: McGill- Queen's University Press, 2000.

Elder, Bruce. Image and Identity: Reflections on Canadian Film and Culture, Waterloo: Wilfrid Laurier University Press, 1989.

Feldman, Seth, Michael Dorland and Pierre Véronneau eds, Dialogue: Canadian and Quebec Cinema, Montréal: Mediatexte Publications, 1987.

Feldman, Seth ed. Take Two: A Tribute to Film in Canada, Toronto: Irwin Publishers, 1984.

Feldman, Seth and Joyce Nelson eds. Canadian Film Reader, Toronto: P. Martin Associates, 1977.

Gittings, Chris. Canadian National Cinema, London: Routledge, 2002.

Harcourt, Peter. Movies and Mythologies: Towards a National Cinema.1977

Jackson, Peter. Maps of Meaning An Introduction to Cultural Geography, London: Rputledge, 1989.

Longfellow, Brenda. "The Crisis of Naming in Canadian Film" in Berland \& Shelly.

Melnyk. One hundred years of Canadian cinema. Toronto: University of Toronto Press, 2004.

Melnyk, George, ed. Great Canadian film directors. University of Alberta, 2007.

Melnyk, G., \& Austin-Smith, B. Eds. The Gendered Screen: Canadian Women Filmmakers. Wilfrid Laurier University. Press, 2010.

Monk, Katherine. Weird Sex \& Snowshoes and Other Canadian Film Phenomena, Vancouver: Raincoast Books, 2001. 
Morris, Peter. David Cronenberg: A Delicate Balance, Toronto : ECW Press,1994.

Morris, Peter. Embattled Shadows: A History of Canadian Cinema 1895-1939, Montreal : McGill-Queen's University Press, 1978.

Norton, W. Cultural geography: Themes, concepts, analyses. Oxford: Oxford University Press, 2000.

Pike, D. L. Canadian Cinema Since the 1980s: At the Heart of the World. Toronto: University of Toronto Press, 2012.

Rist, Peter ed. Guide to the cinema(s) of Canada, Westport, Conn.: Greenwood Press, 2001.

Wise, Wyndham. Take One's Essential Guide to Canadian Film, Toronto: University of Toronto Press, 2001. 